\title{
Indonesian Defense Diplomacy in the Resolution of the South China Sea Conflict
}

\author{
Maulana Anton*, Sukristyanto Agus, Ibnu Achluddin \\ Faculty of Social and Politics, University of 17 August 1945, Surabaya, Indonesia \\ Email address: \\ Agussukris@untag-sby.ac.id (M. Anton) \\ ${ }^{*}$ Corresponding author \\ To cite this article: \\ Maulana Anton, Sukristyanto Agus, Ibnu Achluddin. Indonesian Defense Diplomacy in the Resolution of the South China Sea Conflict. \\ Journal of Political Science and International Relations. Vol. 4, No. 2, 2021, pp. 33-40. doi: 10.11648/j.jpsir.20210402.12
}

Received: March 27, 2021; Accepted: April 10, 2021; Published: April 26, 2021

\begin{abstract}
The conflict in the South China Sea is increasingly being viewed as serious. Historically, conflicts have started from the contested territory between France and Japan, to the result of the power vacuum of the Second World War. There are no international documents that provide clarity on sovereignty in the South China Sea. China, Vietnam, Taiwan, Malaysia, the Philippines, and Brunei Darussalam are countries that have overlapping territorial claims that currently arise more due to domestic economic, geostrategic and political factors. As a non-claimant country, Indonesia has a role to facilitate and resolve the conflict, because Indonesian waters, the North Natuna Sea, also have territorial claims incised. The alignment of the ZEEI and the Nine Dashes has implications for regional economic and defense arrangements. This article uses qualitative analysis methods to explore three objectives. First, explore historical, philosophical and legal approaches in discussing the background to the conflict. Second, analyzing the attitudes and perspectives of Indonesia's strategic position in the South China Sea. Third, proposing several possible recommendations needed by Indonesia to resolve the South China Sea conflict with the roles and actions needed for international and regional goals. Indonesia as a non-claimant country has a diplomatic role as a mediator, honest broker and trust builder in the handling of the South China Sea conflict. Strategic position in the South China Sea proposes several possible recommendations needed by Indonesia to resolve the South China Sea conflict with the roles and actions required for international and regional goals. Indonesia as a non-claimant country has a defense diplomacy role as a mediator, an intermediary that can build trust in the handling of the South China Sea conflict.
\end{abstract}

Keywords: South China Sea Conflict, Territorial Claims, Indonesia Defense Policy

\section{Introduction}

This article aims to analyze the history, philosophy and legal approach in discussing the background of the South China Sea conflict. Second, this article aims to analyze the attitudes and perspectives of Indonesia's strategic position in the South China Sea. In addition, this article will also propose several possible recommendations that are needed by Indonesia as part of Defense Diplomacy in resolving the South China Sea conflict with the roles and actions required for international and regional goals.

The South China Sea conflict is one of the most serious and engaging talks about maritime claims in the region. Last year, the Philippine government supported Vietnam in the case of the sinking of a Vietnamese fishing vessel that was shot by a Chinese boat at the Reed Bank. International has also raised deep concern over it and called on China to be able to exercise restraint in the South China Sea "to stop exploiting the interference or vulnerabilities of other countries to expand unlawful claims in the South China Sea. The Nine Dashes many countries refuse, because it is only based on this. in traditional fishing areas. And the 2016 arbitral tribunal did not recognize when the UNCLOS took effect after it was ratified. The area is also a heated dispute because of its abundant natural resources. important shipping lanes transit points and fishing grounds. Apart from competing economic reasons, historically, there are many perspectives and contexts that have emerged among claimant or non-claiming countries, such as Indonesia and the US.

Several agreements and talks have been undertaken to defuse and resolve the conflict peacefully. In this article, the author tries to find out the perspective and context from the 
Indonesian side as part of Defense Diplomacy. In the end, several recommendations were put forward to help increase Indonesia's role in the field of defense diplomacy in the Asean Region.

\section{Literature Review: Historical Settings of the Conflict}

The sea is essential to human life - it serves as a route of transportation, information and trade. The wide function of the sea makes the sea one of the elements that has the same important function in building international cooperation as well as a source of international disputes. Three quarters of the world's population live in coastal areas. Likewise, $80 \%$ of big cities and almost all international trade centers and military powerhouses are located on the coast [8].

The sea is one of the natural resources that are beneficial to humans, such as oil, gas, fish, minerals, and others. Oil is a strategic resource in a country's economy and industry. The increase in industry has boosted general economic growth. The industrial sector uses the most energy from all forms of resources, including oil, natural gas, and coal, which are used as electricity generation to power industrial equipment. The South China Sea (SCS) is a wide area of serious discussion of late. Historically, before the formation of the nation-state in the Southeast Asia region, SCS clashes had been protracted. The local kingdom at the time seemed to have charted and saw great potential in the South China Sea. Political impetus gradually emerged from the entity to control the South China Sea region, which at that time had shown a crowd of merchant ships. China's increasing need for oil and other energy sources has pushed the country to control the silk route, the South China Sea (SCS).

The Han dynasty, for example, was one of the trade axes that saw this potential, especially the shipping lanes of goods and services. The intensity of the Han dynasty also appears to have triggered local actors around the South China Sea to become actively involved in the struggle for the resources and potential of the South China Sea. For example, the Kingdom of Funan, Kingdom of Angkor, Kingdom of Sriwijaya, Kingdom of Ayutthaya, Kingdom of Champa, and Sultanate of Melaka [9]. Along the way, these local actors take turns controlling the South China Sea to make the most of the high trade flows in the region. In the 8th to 12th centuries, these kingdoms influenced the South China Sea and beyond. However, from the 12th to 15 th centuries, the Chinese fleet commanded by Admiral Cheng Ho dominated the South China Sea. Admiral Cheng Ho who was a Muslim in the end enlivened the symbols of Islam in the archipelago and its surroundings. The situation began to change when Western traders began to arrive, such as from Portugal, Spain, the Netherlands, England, France, supported by the increasingly dominant military capability in the South China Sea which was previously controlled by Arab traders. In the 17 th century, the Netherlands was the most dominant country in the South China Sea region. Entering the 18th and 19th centuries, European colonial domination seemed to decline. However, Britain and France remained in the South China Sea until, eventually, some of their colonies gained independence [9]. The situation began to change when Western traders began to arrive, such as from Portugal, Spain, the Netherlands, England, France, supported by the increasingly dominant military capability in the South China Sea which was previously controlled by Arab traders. In the 17 th century, the Netherlands was the most dominant country in the South China Sea region. Entering the 18th and 19th centuries, European colonial domination seemed to decline. However, Britain and France remained in the South China Sea until, eventually, some of their colonies gained independence [9]. The situation began to change when Western traders began to arrive, such as from Portugal, Spain, the Netherlands, England, France, supported by the increasingly dominant military capability in the South China Sea which was previously controlled by Arab traders. In the 17 th century, the Netherlands was the most dominant country in the South China Sea region. Entering the 18th and 19th centuries, European colonial domination seemed to decline. However, Britain and France remained in the South China Sea until, eventually, some of their colonies gained independence [9]. Entering the 18th and 19th centuries, European colonial domination seemed to decline. However, Britain and France remained in the South China Sea until, eventually, some of their colonies gained independence [9]. Entering the 18th and 19th centuries, European colonial domination seemed to decline. However, Britain and France remained in the South China Sea until, eventually, some of their colonies gained independence [9].

After World War II, there was a power vacuum so that there was not a single international document that provided clarity about sovereignty in the South China Sea. Some of the claims that have emerged today are more due to domestic economic, geostrategic and political factors. China, Vietnam, Taiwan, Malaysia, the Philippines and Brunei Darussalam are the countries that claim this region. This claim was raised again and became more influential in late 2008 when China declared sovereignty over the entire South China Sea region, both waters and the Exclusive Economic Zone (EEZ). This claim will undoubtedly close the opportunity for other countries that are also in dispute to get the top position in this strategic area.

China's claims complicate resolving tensions in the region, especially since China is unwilling to engage in regional negotiations. The SCS territorial conflicts are very complex because of the large number of parties that made claims, including outsiders involved in the dispute, such as the United States (US), which are directly or indirectly in the circle of the South China Sea conflict. The US argues that its involvement aims to carry out one of its roles as a superpower that is responsible for maintaining world security. When China has demonstrated assertiveness in the disputed region, the US is the country that reacts the fastest. In 1999, the US immediately stationed two aircraft carriers in the South China Sea region when China made a strong claim. At 
that time, tensions between Beijing and Taiwan were heating up, which led to an increase in the show of strength of the capabilities of the two countries. China's claims received a negative response. A widespread issue regarding China's claims and attitudes is the state's desire to control the entire South China Sea [7].

China is considered a greedy party and wants to fight over the national territory of the South China Sea to get full access to energy, namely oil and gas in the region [2]. In its foreign policy, China openly states that energy and raw materials are an important source for running the economy [13].

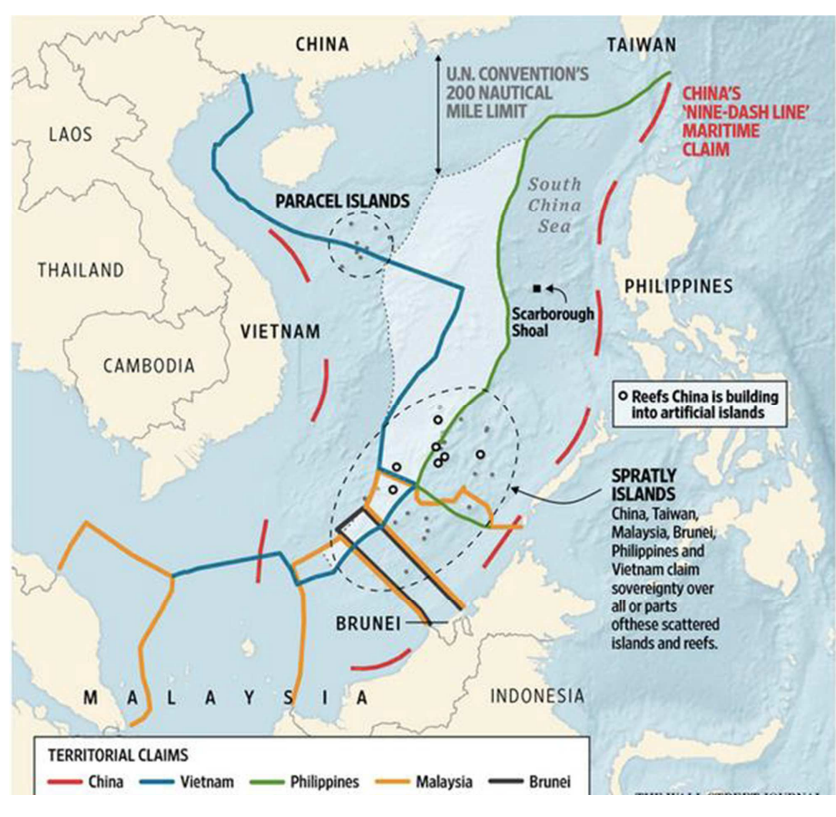

Figure 1. Territorial Claims.

The map above shows some of the intersections and areas of overlap between the six countries in the South China Sea. These lines are the lines drawn by each country with their respective country policies. China had issued a 9-dash line map for historical holdings in 1947. Taiwan occupied Itu Aba Island in 1956. Then, Vietnam designated the EEZ to SCS in 1977, the Philippines issued a Presidential Decree on Spratlys in 1978, Malaysia set the Shelf Continent until SCS in 1979 and Brunei Darussalam established ZEE to SCS in 1988 [6].

Others argue that the desire to reclaim national territory is part of the commitment of the Chinese leaders. This opinion departs from the assumption that control of the South China Sea area means that it will strengthen the bargaining position that can be used at certain times, for example in the negotiation process [4]. China's claim is also an attempt to gain access to fishing, such as in the Hainan region [12]. The South China Sea Sea conflict has involved several international diplomacy processes. Alternative negotiation and cooperation efforts are also proposed as a settlement process. Until mid-2016, there were no signs that the conflict in the regions would end; it was even getting hotter.

In June 2011, Vietnam accused China of cutting off its oil and gas exploration route. According to Vietnam, this is the second time China has done the same thing [10]. As a result of the feud, each party's actions invited the other's response. Vietnam bought Russian submarines, responding by increasing its military training activities. China also stated that the number of troops stationed in the SCS area will continue to increase until 2020. Not only with Vietnam, tensions between China and the Philippines are also increasing. Since 1992, military cooperation between the Philippines and the US has improved, particularly for counterterrorism and maritime security purposes. In its security policy agenda, the US also stated that one of the country's goals "Its policy is to increase alliances with the Philippines". The main reason is for stability [5].

Tensions in the South China Sea have escalated following increased cooperation between the US and the Philippines, especially the intensive military exercises between the two countries. This cooperation is an effort to provide security for oil exploration in the South China Sea. This joint exercise sparked concern and Chinese reaction, which in turn caused tensions in the South China Sea to worsen [1]. The enormous potential of natural resources has undoubtedly triggered competition between countries in the South China Sea for control of the region. Most of the claimant states in the South China Sea have claims to various actions. A series of islands totaling more than 30,000 islands, including coral clusters, are not only rich in natural resource potential, however, the strategic position of the South China Sea has also become the target of many countries to serve as a defense system. As a result, the escalation of the conflict appears to be a grave threat in the South China Sea. In particular, several countries officially claim the South China Sea. For example, the Paracel Islands which are claimed by three countries, namely China, Taiwan and Vietnam. At the same time, the Spratly Islands became a place of struggle between China, Taiwan, Malaysia, the Philippines, Vietnam and Brunei Darussalam. Adjacent to the Spratly Islands, there is a disputed coral cluster between the Philippines, China and Taiwan known as the Scarborough Shoal. The main source of the South China Sea conflict is related to the "nine dash line" area which is the most fuel for regional tensions,

The existence of these various claims can undoubtedly have an impact on the escalation of conflict on a larger scale. In fact, many tensions have arisen from the mutual claims activity in the LCS. In this context, the US position is exciting. Apart from being a serious competitor to China in the South China Sea, the US is apparently very interested in the region. The US has two main interests, namely access to shipping and political stability and security of the South China Sea. For the US, it is very important to be able to use SCS dispatch access freely. In addition, maintaining the stability of the SCS also means maintaining the stability of Southeast Asia which is very important for the US [3]. In the view of US Secretary of State Hillary Clinton, the US has a "national interest" in the South China Sea and hopes that all countries, including China, to respect international law. The US itself refuses to ratify international maritime law or the United Nations Convention on the Law of the Sea (UNCLOS) 
[11].

Claims made by China that have no legal basis recognized by international law, particularly UNCLOS 1982. China constantly makes claims and practices to occupy and manage important activities. The Chinese government at the official level under the Minister said that they did not experience territorial problems. This statement entertained the Indonesian government, especially the Indonesian Foreign Minister. Even so, Indonesia has made two protests to the UN in 2010 and 2020. The cross line problem in the EEZ region is determined by the two countries. China should have corrected the line that was cut with Indonesian territory. China's ambiguous attitude, for reasons of historical reasons. The second reason is because the weather at certain times in the northern SCS experiences winter so that fishermen cannot catch fish. so that they shifted south to enter the EEZ region which is in contact with the Indonesian national territory. That's where it happened; Indonesian institutions catch Chinese fishing vessels. China always says if there is a dispute, then just leave it alone until it is brought to the official forum. This intention is a political strategy carried out by China. The Indonesian government has carried out various efforts as a defense diplomacy strategy.

As a non-claimant country, Indonesia's position can increase lobbying against China, so that the problems of the two countries can be resolved adequately. From a geopolitical point of view, the position of the SCS is very strategic in the movement of the forces of the two navies connecting between continents. In principle it is very strategic; whoever determines geostrategy in SCS then determines the domains around SCS and the world. In terms of territorial sovereignty and domestic politics, this determination will recognize the legitimacy sovereignty of the ruling regimes in their respective countries. Moreover, Indonesia is the founder of ASEAN. Indonesia's existence in this regional area must be strengthened. Indonesia can be a mediator, an honest broker, or a trust builder capable of bringing claim states to the negotiating table.

This approach was successfully implemented during the SBY administration; At that time Marty Natalegawa as Foreign Minister brought problems at the negotiating table which resulted in several commitments, including the Code of Conducts of all the countries involved. The point is that the South China Sea issue will be resolved peacefully. Indonesia's claims use UNCLOS 1982 articles 55, 56, and 57. The claim also had a settlement with Malaysia and Vietnam on the Continental Shelf in 2004. Then, in 2016, the dispute between the Philippines and China, all maritime features in the South China Sea Sea were not entitled to determine EEO because all of them do not meet the requirements as islands. So that in the South China Sea these countries only have claims of $12 \mathrm{~nm}$ as territorial. Traditional fishing rights do not exist in the definition of territorial claims, so this recognition of China is one-sided. However, not all ASEAN countries side with Indonesia, because several countries are "friends". from China. Therefore, there is no compromise and further discussion between Indonesia and China because there are no borders.

\section{Indonesia's Perspective and Context: Disputes in Natuna's North Water}

There are several points of view of the Indonesian government in viewing the Sea Ocean Sea as a very strategic area. First, in a political context, there is a paradox of the struggle for power and influence. This area is a battle between state classes, ranging from large, medium-sized countries to states. A more significant struggle for influence can be seen in the restructuring efforts between state actors that are mutually challenging. Each country will look for who is the most superior in this class battle. Then, on the other hand, a pseudo power relation will emerge. In this area, regionalities, communities and alliances that have the same interests and strategic objectives will be formed.

Second from a security point of view, it relates to the political interests of regional countries. The arms race, the struggle for influence, and regional security are the main agendas of each country, which often contribute to debates in international relations. Such a situation will lead to a power struggle to become a "leader" in the region. The imbalance in the size of the defense budget is also a consideration for how they will find friends or strategic alliances, for example informing the defense community. A country that has a firm policy supported by a strong military force will become the leader who controls regional security.

Third trade traffic and natural resource reserves are the main commodities in the South China Sea. Access, exploration and exploitation of natural resources in the South China Sea are the main motives in providing regional or foreign countries to determine wise steps, especially in the economic and business fields. Fourth, this regional perspective can also be viewed in terms of socio-cultural factors. Values, norms, language, customs and habits are also often considered by state leaders in the region.

Some context is needed to provide understanding and input from decision and policy makers in dealing with this situation. At this time, at the global level, there is a battle between major countries that give each other influence and power, for example the US - China in the Pacific and South China Sea. The growing importance of the region makes anyone who plays in the region a global battle of power. The US itself is changing its policy direction towards the Indo Pacific, just as China is increasingly showing its strength in the South China Sea. China may be able to lead like the US has done in all corners of the world, even though we know the US is also experiencing a decline. China's Peaceful Awakening, which later became OBOR and the Belt and Road Initiative. More and more big state actors are starting to show the same interests and policies towards the South China Sea. For example, India, made a policy towards the Indian Ocean towards the South China Sea. This region will be a bipolar and multi-polar relationship of power, struggle and competition in the long-term strategy. 
At the regional level Security, particularly in the regional economy, was greatly affected by the failure of the Doha Round Development Agenda, which resulted in a shift in the agreement towards bilateral or regional trade agreements. The problem is that the increasing number of trade agreements presents other complications for the Asia Pacific region, such as trade diversion and the bowl noodle effect. This increase then led to the emergence of a new era of more significant free trade regional agreements related to areas with the main distribution of world trade, called Megar Regional Trade Agreements (MRTAs). The Trans-Pacific Partnership (TPP), led by the United States and the Regional Comprehensive Economic Partnership (RCEP) with China as the main mechanism, is the most ambitious MRTA in Asia Pacific. Two problems in the two agreements are, The emergence of the two MRTAs shows the economic dynamics in the Asia Pacific region. Two issues that embody these dynamics are, first, the TPP and RCEP are ways to realize Asia Pacific integration because the significant economic potential reaches 67 percent of global GDP in 2015. Second, there are differences in economic interests between initiating countries such as the United States in the TPP and China at RCEP presents another challenge to the process of economic integration in the Asia Pacific region. The emergence of China in the competition for economic hegemony through various reform policies of BUMN (State-Owned Enterprises) and its agricultural sector, increased productivity and opened a previously closed market to competition that is now competing with the United States. This condition then prompted the United States to emphasize the axis politics to the Asia Pacific with the TPP as one of the strategies in maintaining its economic hegemony. Various integration efforts will fulfill the fact of competition between the US TPP with a background of Unilateral Hegemony and China's RCEP with Cooperative Hegemony. In this case, Indonesia prioritizes the RCEP agreement over the TPP on economic and non-economic grounds. It is said that China won the RCEP over the US TPP. Although economic power is still losing to the US, China is starting to win in economic victories in the region and become the economic leader in the region. The situation in the South China Sea will always affect the regional environment, which shows predictions that it will continue to heat up, along with the Chinese military campaign in the region. This condition causes the sovereignty of the Indonesian nation to be potentially threatened, especially in the waters of the North Natuna Sea. Likewise with the reactions of other countries that have contributed significantly to the intelligence analysis process and at the national level of policy makers.

Even though Indonesia is not a claimant state, the involvement of other countries, such as the US, is quite draining when these countries play in the front yard of Indonesia's home. It is a clear example that the US recently, firmly rejects all of China's claims and views the Chinese Communist Party (CCP) as a threat to India and Southeast Asian countries. In response to the threat, the country led by Donald Trump will reduce the number of troops in Europe.
Later, troops will operate in other areas that have the potential to become targets of the Chinese government. This condition makes Indonesia and countries in Southeast Asia carry the ASEAN Outlook on Indo Pacific, the goal is to encourage cooperation, not competition. ASEAN Outlook on Indo Pacific is an affirmation from ASEAN ' In the national context, the threat of communism has also become a prominent discourse. China continues to be active in military, economic and industrial hegemony, using the principle of soft diplomacy. The communist party rebellion in 1965 was traumatic for some Indonesians. The understanding that China's development in the South China Sea is towards the south is in the sense of communism when viewed from the side of Indonesia's national sovereignty. Indonesia's policy to develop the local context in facing potential threats from the South China Sea shows progress. For example, the construction of the outer islands which are the sea borders, namely Natuna Island. The formation of an Integrated Military Unit in Natuna was apparently not in line with the development of the welfare and security of the local community. The development of Natuna Island is still very minimal; Neither the welfare of the Natuna community nor the infrastructure development looks more comprehensive. The use of the TNI and Polri is part of efforts to accelerate development on Natuna Island.

\section{Indonesia's Position in Defense Strategies and Political Arrangements}

Conditions on land can also occur at sea. When that happens on land, it may be easy to prove, investigate, and proceed. However, if it happens at sea, it will involve and tend to be complicated. This incident is because the target object is a foreign entity. Such scenes will be difficult to reconstruct - for example, illegal fishing, arm robbery, human trafficking and more. The problem of foreign fishing vessels in Indonesia is still high, including China, which shows a relatively high number after this international decision. Then Vietnam, the Philippines, and Malaysia are still relatively high, with Vietnam also accompanied by clashes of law enforcement vessels at sea. Thailand, Singapore, PNG, Timor Leste, and India are still very low, which are dominated by fisheries. All of the incidents that occurred were IUU fishing boat activities which developed into an inter-state issue. In the South China Sea, viral events have emerged in much analysis and debate. Most of the crime scenes have not occurred at sea borders. When there are no clear boundaries, the potential for increased incidence intensity becomes a problem between countries.

In the EEZ, the right of a country to carry out exploration and exploitation. There, the state's right to enforce the law; in this case the subject of the activity is fishing vessels, coast guards, and warships. Conflicts between law enforcement officers and fishermen, for example, are doubts about whether orders were conveyed, different languages, and law enforcement officials with other state law enforcement 
officials. These two are usually followed by dangerous maneuvers, ship collisions, provocative actions, etc. To resolve this situation, the diplomatic record is the only strong statement. Many countries accept UNCLOS widely because of the language it uses in general. Thus, the interpretation and understanding of each country can be different and sometimes lead to debate and disputes regarding the definition. The fishing case contains live release, temporary measures, and the use of force. Therefore, law enforcement at sea is not easy. Given an improper fine, a ship carrying its country's flag can take the challenge to a higher level (UNCLOS). In the case of the North Natuna Sea, Indonesia's EEZ comes into contact with the 9 Chinese lines as far as $83,000 \mathrm{~km} 2$, which China claims as a traditional fishing ground since the Tang Dynasty (618 AD) and is recorded in the history of the Song Dynasty. (960 AD) and the Han Dynasty (AD 25). Chinese fishing vessels often operate in the North Natuna Sea, arrests by Indonesian security forces based on illegal fishing triggered the arrival of the Chinese coast guard to request release. Therefore, in the eyes of the defense strategy,

First, the domestic approach applies the strengthening of military bases close to conflict areas. Although the construction of a joint and integrated military base in Natuna continues, at present these efforts have not had a frightening impact on China. Second, the TNI conducts military exercises around the South China Sea, but this approach is an alternative approach or the last approach. The TNI has conducted several military exercises in the North Natuna Sea, namely 12 days of TNI-Naval training in June 2016 and Air Force War Training in October 2016. Furthermore, the Indonesian government needs to take several law enforcement and defense measures to withdraw. Chinese ships, such as driving out of ships from Indonesia's EEZ, increase the intensity of patrols in the Natuna Sea.

Third Changing its name to North Natuna Sea is a brilliant step taken by Indonesia. Fourth, flashpoint-based defense in the Indonesian Armed Forces (IAF) Minimum Essential Strength (MEF) by allocating personnel to areas with potential for conflict, including around the South China Sea. So that Indonesia's position is recognized by Southeast Asian countries. The existence of Indonesia must play a role again in ASEAN by increasing the IAF budget to accelerate the achievement of the MEF so that Indonesia has a calculated defense force in the region, especially the South China Sea. Finally, the Government mobilized and escorted Indonesian fishermen operating in the South China Sea. The four efforts can provide an illustration to China that Indonesia will utilize existing resources to defend Indonesia's EEZ region. Indonesia also needs to prepare a political strategy in dealing with the situation in the South China Sea. First, the external institutional balance through the use of ASEAN institutions to bring together disputing parties in the South China Sea conflict. Second, balancing domestic institutions by enhancing domestic security and institutional capacities to create a deterrent effect. Third, reframing as a fisheries issue, namely by seeing disputes in the EEZ as a bilateral IUU fishing case, not as a matter of sovereignty.

\section{Recommendation}

This article proposes several recommendations to the Government of Indonesia. First, clarifying and strengthening the coast guard mechanism in the waters of the South China Sea in particular. Indonesia can have a maximum force mechanism by giving a mandate to the TNI or using a minimal force mechanism by giving a mandate to the coast guard and special waters such as the Maritime Security Agency (Bakamla) or increasing cooperation between the two parties in its implementation. maritime security. The increase in the defense budget of up to 130 trillion rupiah has not been able to prepare and reach the TNI MEF both in quantity and quality. An increase in the budget for maritime defense and security will also not be able to keep up with the development of the situation and the development of a very dynamic regional power. Indonesia does not want the islands of Sipadan and Ligitan to happen again. Moreover, Indonesia does not want to lose even an inch of its country to return to foreign ownership.

Second, strengthen sanctions in Indonesia's EEZ region to countries that claim conflict zones. This recommendation is needed because of the attitude of the Indonesian Government which tends to be passive because it is not quite right. Recognizing Indonesia's bargaining position in the economy as a large market and having good relations with China in the economic and investment fields, it should be able to impose sanctions on violations in the Indonesian EEZ region as can be done without worrying about losing economic relations. Conflict must be brought to the negotiating table, either through the first route or the second route.

Third, conduct preventive defense diplomacy in handling IUU fishing in the North Natuna Sea. Preventive diplomacy efforts to prevent the practice of IUU fishing, including through bilateral negotiations to mutually recognize UNCLOS laws or multilateral forums such as the ADMM. Efforts to help the mobilization of Indonesian fishermen do not directly cover fishery resources, both in quantity and quality, with the aim of improving fishermen's welfare. Fourth, increasing leadership in ASEAN in regional Code of Conduct negotiations. Indonesia must return to the chair of leadership and establish trust-building steps to create mutual trust so that Code of Conduct negotiations can be completed properly and on time. Fifth, increasing security cooperation with pacific countries. Increased cooperation with Pacific countries, particularly on security, could have a balancing effect on China's behavior in the region. The concept of the Indo Pacific community can increase the solidarity of countries in Southeast Asia and the Pacific in facing China's aggressive behavior in the South China Sea. Sixth, take advantage of Indonesia's membership in the UN Security Council for the 2019-2020 period to bring the issue of stability in the Asia Pacific region to international attention. 
The stability of this region is very important because it is a strategic area for world trade and distribution routes. If necessary, Indonesia proposes to redesign UNCLOS, including inviting China to participate in drafting articles at UNCLOS. could have a balancing effect on Chinese behavior in the region. The concept of the Indo Pacific community can increase the solidarity of countries in Southeast Asia and the Pacific in facing China's aggressive behavior in the South China Sea. Sixth, take advantage of Indonesia's membership in the UN Security Council for the 2019-2020 period to bring the issue of stability in the Asia Pacific region to international attention. The stability of this region is very important because it is a strategic area for world trade and distribution routes. If necessary, Indonesia proposes to redesign UNCLOS, including inviting China to participate in drafting articles at UNCLOS. could have a balancing effect on Chinese behavior in the region. The concept of the Indo Pacific community can increase the solidarity of countries in Southeast Asia and the Pacific in facing China's aggressive behavior in the South China Sea. Sixth, take advantage of Indonesia's membership in the UN Security Council for the 2019-2020 period to bring the issue of stability in the Asia Pacific region to international attention. The stability of this region is very important because it is a strategic area for world trade and distribution routes. If necessary, Indonesia proposes to redesign UNCLOS, including inviting China to participate in drafting articles at UNCLOS. The concept of the Indo Pacific community can increase the solidarity of countries in Southeast Asia and the Pacific in facing China's aggressive behavior in the South China Sea. Sixth, take advantage of Indonesia's membership in the UN Security Council for the 2019-2020 period to bring the issue of stability in the Asia Pacific region to international attention. The stability of this region is very important because it is a strategic area for world trade and distribution routes. If necessary, Indonesia proposes to redesign UNCLOS, including inviting China to participate in drafting articles at UNCLOS. The concept of the Indo Pacific community can increase the solidarity of countries in Southeast Asia and the Pacific in facing China's aggressive behavior in the South China Sea. Sixth, take advantage of Indonesia's membership in the UN Security Council for the 2019-2020 period to bring the issue of stability in the Asia Pacific region to international attention. The stability of this region is very important because it is a strategic area for world trade and distribution routes. If necessary, Indonesia proposes to redesign UNCLOS, including inviting China to participate in drafting articles at UNCLOS. The stability of this region is very important because it is a strategic area for world trade and distribution routes. If necessary, Indonesia proposes to redesign UNCLOS, including inviting China to participate in drafting articles at UNCLOS. The stability of this region is very important because it is a strategic area for world trade and distribution routes. If necessary, Indonesia proposes to redesign UNCLOS, including inviting China to participate in drafting articles at UNCLOS.

\section{Conclusion}

Indonesia has no disputes with China and other claimants over the South China Sea issue. The dispute in North Natuna waters occurred due to economic, geo-strategic and political reasons. Indonesia's attitude towards China in the South China Sea depends to a large extent on the choice of Indonesia's perspective and Indonesia's interests. In maintaining sovereignty, Indonesia needs to consider Indonesia's military strength and means of defense diplomacy as well as the role of mediators, honest intermediaries and trust builders in handling the South China Sea conflict. As a non-claimant state in the SCS, Indonesia needs to maintain its sovereignty, regional stability and national development. One of them, Indonesia pays more attention to the outermost, frontier and underdeveloped areas.

\section{References}

[1] Alexander, David and Manuel Mogato. "US and Philippine Defense Eyes Stronger Bond." Reuters. http://www.reuters.com/article/20 12/01/26 / us-PhilippinesusidUSTRE80P22320120126 (last accessed March 26, 2021).

[2] Dobson, Willian J. and M. Taylor Fravel. "Red Herring Hegemon: China in the South China Sea." Current History (September 1997). Fravel, TM (2012). US and China in Regional Security: Implications for Asia and Europe Paper presented at the Berlin Conference on Asian Security 2012, Berlin.

[3] Fravel, T. M. (2012). The U.S. and China in Regional Security: Implication for Asia and Europe Paper presented at the Berlin Conference on Asian Security 2012, Berlin.

[4] Hyer, Eric. "The South China Sea Dispute: Implications for Previous Chinese Territorial Settlements." Pacific Affairs, Vol. 68, No. 1 (Spring 1995), pages 34-54.

[5] Lunn, J. (2016) The South China Sea Dispute: January 2016 Update. Brief Paper No. 7481, 28 January 2016. London: House of Commons Library. Mapendere.

[6] Qi, Huaigao. Joint Development in the South China Sea: Incentives and policy options. Journal of Contemporary East Asian Studies, $8: \quad 2, \quad 220-239, \quad$ DOI: 10.1080/24761028.2019.1685427.

[7] Smith, Esmond D., Jr. "China's Aspirations in the Spratly Islands." Contemporary Southeast Asia, Vol. 16, No. 3 (Desember, 1994), page. 274-294.

[8] Till, Geoffrey. Seapower: A Guide for the Twenty-First Century. New York: Routledge, 2009.

[9] Tonnesson, S. (2001) An International History of the Dispute in the South China Sea. EAI Working Paper No. 71. Singapore East Asian Institute, National University of Singapore.

[10] Wines, Michael. "Dispute Between Vietnam and China Escalates Over Competing Claims in the South China Sea." New York Times. http://www.nytimes.com/2011/06/11/world/asia/11 vietnam.ht $\mathrm{ml}$ ? $\mathrm{r}=1$. 
[11] Yujuico, E. (2015) The real story behind the South China Sea dispute. Situation Analysis. London: London School of Economics and Political Science.

[12] Zha, Daojiong. "Localizing the South China Sea Problem: The Case of China's Hainan." Pacific Review, Vol. 14, No. 4 (2001), page. 575- 598.
[13] Zweig, David dan Bi Jianhai. "China's Global Hunt for Energy." Foreign Affairs, Vol. 84, No. 5 (September-Oktober 2005), page. $25-38$ 